\title{
Effectiveness of Positive Deviance, an Asset-Based Behavior Change Approach, to Improve Knowledge, Attitudes, and Practices Regarding Dengue in Low-Income Communities (Slums) of Islamabad, Pakistan: A Mixed-Method Study
}

\author{
Muhammad Shafique ${ }^{1}\left(\mathbb{D}\right.$, Muhammad Mukhtar ${ }^{2}$, Chitlada Areesantichai $^{1,3}$ and Usaneya Perngparn ${ }^{1, *}$ \\ 1 College of Public Health Sciences, Chulalongkorn University, Bangkok 10330, Thailand; \\ muhammad.shafique2002@gmail.com (M.S.); chitlada.a@chula.ac.th (C.A.) \\ 2 Directorate of Malaria Control, Islamabad 44000, Pakistan; mukhtarnih@gmail.com \\ 3 Health and Social Science and Addiction Research Unit (HSSRU), Bangkok 10330, Thailand \\ * Correspondence: usaneya.p@chula.ac.th
}

Citation: Shafique, M.; Mukhtar, M.; Areesantichai, C.; Perngparn, U.

Effectiveness of Positive Deviance, an Asset-Based Behavior Change Approach, to Improve Knowledge, Attitudes, and Practices Regarding Dengue in Low-Income Communities (Slums) of Islamabad, Pakistan: A Mixed-Method Study. Insects 2022, 13, 71. https://doi.org/ $10.3390 /$ insects 13010071

Academic Editor: Hans J. Overgaard

Received: 27 October 2021

Accepted: 5 January 2022

Published: 8 January 2022

Publisher's Note: MDPI stays neutral with regard to jurisdictional claims in published maps and institutional affiliations.

Copyright: (C) 2022 by the authors. Licensee MDPI, Basel, Switzerland. This article is an open access article distributed under the terms and conditions of the Creative Commons Attribution (CC BY) license (https:// creativecommons.org/licenses/by/ $4.0 /)$.
Simple Summary: Dengue is a mosquito-borne infection caused by the Aedes mosquito, expanding at an alarming pace around the world. Recently, Pakistan has witnessed some major dengue outbreaks, affecting thousands of individuals across the country. As there is no specific cure or vaccine, prevention and vector control remain the key methods to avoid dengue infection. In Pakistan, dengue control activities are mainly focused on information-sharing through mass media and communication materials such as pamphlets and posters. The main challenge is a lack of community participation that can create an enabling environment for communities to follow the desired behaviors. There is a strong need to design and implement community-led behavior change approaches to ensure community participation and translate the knowledge into practices. This study was conducted to better understand the effectiveness of a community engagement approach, 'positive deviance', on dengue prevention and control. The study was carried out in two slums affected by the recent dengue outbreak in Islamabad, Pakistan. A total of 112 persons participated in the study, which was conducted from June-October 2020. The community discovered already-existing positive behaviors surrounding dengue prevention and control, which were shared with other participants through interactive activities. The study demonstrated positive changes in knowledge, attitudes, and practices, and could be a potential tool for dengue prevention and control programs worldwide.

Abstract: Dengue is a mosquito-borne, viral disease that has emerged as a global health concern in recent years. In the absence of specific antiviral treatment and vaccines, prevention remains the key strategy for dengue control. Therefore, innovative and community-driven approaches are required to improve the vector control practices. This study applied and evaluated the positive deviance (PD) approach on dengue prevention and control in selected slums of Islamabad during June-October 2020. The two most dengue-affected slums, the Faisal colony and France colony, were purposively selected as intervention and control groups, respectively. A total of 112 participants (56 for the intervention and 56 for the control group) participated in the study. The intervention group was exposed for two months to locally identified role model behaviors through weekly interactive sessions, dengue sketch competitions, and role plays. Another two months enabled the community to practice these behaviors without any external support in order to explore the intervention's sustainability. Three surveys were conducted: before the intervention, after two months, and after four months, to assess any changes in the knowledge, attitudes, and practices of participating communities. Results found that the PD intervention had a significant positive impact on dengue knowledge, attitudes, and practices in the intervention group. PD could offer an empowering and efficient community engagement tool for future dengue prevention and control, both in Pakistan and more globally. 
Keywords: dengue; prevention; positive deviance; behavior change; community participation; slums; Pakistan

\section{Introduction}

Dengue, a mosquito-borne, viral disease, has emerged as a global health concern in recent years. Dengue is prevalent in 128 countries, mostly in the tropical and subtropical regions of the world [1,2]. Dengue has four serotypes (DENV) and is primarily vectored by Aedes aegypti mosquitoes [3]. Dengue cases have been significantly increasing globally, with an estimated 390 million dengue infections per year [4]. Population growth, urbanization, climate change, and international travel have contributed to the rapid increase in dengue worldwide [5-8].

Dengue has spread dramatically in Pakistan in recent years $[9,10]$. The first confirmed dengue outbreak was reported in the economic hub of Pakistan, Karachi, in 1994 [11]. Pakistan suffered major dengue outbreaks during 2006, 2007, 2008, 2010, and 2011, which severely affected thousands of individuals and claimed hundreds of lives [12]. An estimated 24,938 dengue virus infections were recorded from 15 districts of Khyber Pakhtunkhwa in 2017 [13]. However, the worst dengue outbreak was recorded in 2019, which caused 56,000 dengue cases and claimed 95 deaths in Pakistan [14]. An estimated $43 \%$ of dengue cases were reported from Islamabad and Rawalpindi.

Currently, there is no antiviral treatment available for dengue. Although several dengue vaccines are in the clinical development process, however, it will take them years to be rolled out in Pakistan to provide protection against dengue $[15,16]$. Therefore, in the absence of specific treatments and vaccines, prevention remains the key method for dengue control. Therefore, local, context-appropriate, community-driven, and sustainable behavior change communication strategies are required for the effective prevention and control of dengue $[17,18]$. However, the key challenge to carrying out effective community-based dengue programs is the lack of community participation in vector control interventions [19]. The importance of community involvement in health and development programs has been stressed in the Alma Ata Declaration held in 1978, and thereafter has been a core goal of health planners and practitioners [20].

As the breeding of dengue vectors depends on human behavior, there is a dire need to involve local communities as active partners in the design, implementation, and monitoring activities of dengue control programs [21,22]. The active involvement of communities in the design, planning, and most important decision making creates strong ownership and acceptance which fosters the sustainability of the interventions [21-24]. This study applies positive deviance, a community engagement approach to improve vector control behaviors in Islamabad, Pakistan.

\section{Positive Deviance}

Positive deviance (PD) is a community engagement approach to behavior change. PD was initially envisioned on nutrition studies and operationalized to improve nutrition outcomes in Vietnam. The successful nutrition experience was later replicated in over 40 countries all over the world [25-28]. The PD approach has recently been employed on a variety of public health issues which include maternal and newborn health, diabetes care, and malaria prevention and control [29-31].

The PD premise is that in every community, there are a few 'positive deviant' persons who deviate from social norms and practice uncommon behaviors that help them and their families to enjoy better health outcomes than their peers and neighbors with whom they share similar risks and resources. PD emphasizes that solutions to most health and social problems already exist in the same communities. In contrast to the need-based problem-solving approaches which look at what is missing and try to fix it, PD focuses on what is working and building on the existing strengths. These local, accessible, and 
acceptable solutions are then shared with other community members through an interactive implementation program to foster positive changes in their behaviors. These PD individuals or 'role models' have strong ownership and acceptance of their fellow community members, who can better relate to their messages and behaviors than those which are delivered by external bodies. Expert-driven approaches often fail, as the community members do not relate to those external messages and behaviors and discontinue them as soon as the externally designed and delivered intervention is complete [32]. On the other hand, the PD approach ensures a sense of belonging by identifying role models from within the community with similar resource bases and challenges. PD behaviors are simple, and therefore accessible, affordable, and replicable by the other community members facing similar risks [33]. Furthermore, active community participation throughout the process guarantees community acceptance and ownership which fosters sustainability, even years after the intervention has been completed [34].

Despite a widespread application of positive deviance as an empowering tool on a variety of public health issues, PD has never yet been employed on dengue prevention and control. PD could offer an empowering and efficient community engagement tool for dengue prevention and control. This study aims to assess the effectiveness of the PD approach on dengue prevention and control in the selected slums of Islamabad. As dengue is a newly emerging disease, there is a limited understanding and evidence of the role of communities on dengue control in Pakistan.

Therefore, this PD study will pave the way for further community engagement research and will provide rich insights to the concerned partners on the importance of community participation in dengue control and spread.

\section{Materials and Methods}

\subsection{Study Setting}

Two low-income communities often referred to as slums, Faisal colony and France colony, were purposively selected for the study. The estimated population of Faisal colony was 4000 persons (450 households) and the estimated population of France colony was 4500 persons (500 households). In 2019, Pakistan experienced one of the worst dengue outbreaks, with 50,535 dengue cases and 83 deaths. An estimated 43\% cases were reported from Islamabad and Rawalpindi. The two selected communities were among the mostaffected areas of the recent dengue outbreak.

Faisal colony was selected to receive the intervention, with France colony selected as the control group. The population of the selected slums were predominantly Christian with similar socioeconomic characteristics. The geographical distance between the two communities was around $4 \mathrm{KM}$.

\subsection{Study Design and Sampling}

A mixed method quasi-experiment was conducted in two purposively selected, highrisk dengue slums in Islamabad during June-October 2020. Convenience sampling was used to recruit 112 respondents; 56 were assigned to the intervention arm and 56 were assigned to control group. The study participants were selected based on the list of households. The households were contacted to ask for their willingness to participate in the study. One person was selected per identified household for the study. The estimated sample size was calculated using a power analysis with $G^{*}$ Power 3.1 [35]. The effect size was calculated using a previous study [36]. A power of 0.8 was based on the effect size of 0.59 to account for the difference in dengue knowledge between groups, which is the primary outcome. The power analysis contained four independent variables:

$\beta \quad$ Beta error, where power $=(1$-Beta error $): 0.8$

$\alpha$ Alfa error rate: 0.05

E Effect size: 0.59

$\mathrm{N}$ Sample size: 92 
The total sample size included 92 participants, where 46 participants were divided into two groups. After calculating the drop-out rate of $20 \%$, the total sample size was 112 , which resulted in 56 participants per group. ANOVA: repeated measures, between-within interactions. Sample size calculation:

Effect size

$$
\begin{gathered}
f=\frac{\sigma_{\mu}}{\sigma} \\
\lambda=f^{2} \mu N_{\varepsilon}
\end{gathered}
$$

when

$$
\begin{gathered}
\mu=\frac{m}{1-\rho} \\
d f_{1}=(k-1)(m-1) \varepsilon \\
d f_{2}=(N-1)(m-1) \varepsilon
\end{gathered}
$$

The questionnaire formerly used for a previous PD study in Cambodia was modified for this study [37]. Face-to-face interviews were conducted in the Urdu language. In June, a Knowledge, Attitude and Practices (KAP) survey was conducted to establish the benchmark in each slum. At the end of the two-month intervention, the KAP survey was repeated. In October, the KAP survey was repeated a third time to assess any changes in the knowledge, attitudes, and practices among study participants. The survey tool included questions about: (1) demographic and socioeconomic information which included age, gender, religion, marital status, education level, and the respondent's monthly income; (2) knowledge about dengue transmission and symptoms; (3) health-seeking behaviors; (4) attitudes towards dengue; (5) personal protection measures and methods to avoid breeding sites; and (6) preferred channels of communication. The questionnaire was pretested with 30 participants for internal consistency and finalization of the tool.

For the qualitative component, eight focus group discussions (FGDs) were carried out with male and female community members to explore in depth their knowledge, perceptions, and practices regarding dengue. Ten in-depth interviews (IDIs) were conducted to identify and select the positive deviance role model behaviors from the communities. Topic guides were developed in the local language (Urdu) to conduct face-to-face interviews with the participants. The findings of the qualitative component formed the basis of the PD-informed intervention.

\subsection{Training of Data Collectors}

Local college students with some previous experience in the research were recruited for the study. Two days of training were organized, covering informed consent, research ethics, interviewing skills, probing and notetaking skills, topic guides (for the qualitative component), and the survey questionnaire.

\subsection{Data Management and Analysis}

The data were entered in the Epi Data 3.1 software (Epi Data Association, Odense, Denmark), cleaned, and then exported to the Statistical Package for Social Science (IBM SPSS Statistics 25) for detailed analysis. During the statistical processing of data, standard methods of descriptive statistics were used. Variables of interest were tested for normality, mean and median were used to describe continuous data, and frequencies and percentages were used to describe categorical data. Chi squire $\left(\chi^{2}\right)$ tests and Fisher's Exact tests were performed to examine differences between the intervention and control group at the baseline. Based on a total number of correct answers, new variables were created to examine dengue knowledge (0-48), attitude (0-32), and practice (0-24). To the options for the attitude statement answers, 'Strongly agree', 'Agree', 'Disagree' and 'Strongly disagree' were assigned points of 4,3,2, and 1, respectively. For scoring purposes, negatively worded items were reverse coded. For the purposes of descriptive analysis, the answers to the statements related to dengue attitudes were collapsed into a 3-point scale ('Agree', 'Don't 
know, and 'Disagree'). A repeated-measures mixed ANOVA, with one within-subjects factor (time) and one between-subjects factor (group), was conducted to compare the mean differences in total dengue knowledge, attitude, and practice scores between the intervention and control group over time, i.e., baseline, midline after two months, and end-line after another two months.

\subsection{Ethical Consideration}

The study protocol was approved by the National Bioethics Committee, Pakistan in April 2020 (Ref: No.4-87/NBC-451/20/2037). All the respondents were informed about the voluntary nature of the participation, possible risks and benefits, and the expected duration of the interview. Written informed consent was taken from each participant. The Government of Pakistan's Standard Operating Procedures (SOPs) for COVID-19 were carefully followed during the interviews.

\subsection{Positive Deviance Intervention}

The positive deviance study was carried out in two phases; (1) One-week PD process; (2) Two-month implementation of PD intervention. The details of the PD implementation are as follows:

\subsubsection{Phase 1. PD Process (One Week)}

The interactive one-week PD process helped mobilize and sensitize the communities for dengue prevention and control. The PD process enabled communities to understand the normative behaviors around dengue and discover uncommon positive deviant behaviors and strategies of role models that were already being practiced in the communities. The following activities were carried out in the PD process:

- Community sensitization meeting

A community sensitization meeting was held with key community stakeholders including religious leaders, teachers, and influential persons to introduce the PD concept through different interactive activities such as storytelling and conceptual games in the selected communities. Interested community members were identified as volunteers to provide support in the next step, i.e., the situation analysis (Figure S1, Community sensitization meeting).

\section{- Situation analysis}

The situation analysis helped establish the normative behaviors around dengue prevention and control. A total of eight FGDs were carried out with male and female community members to explore their knowledge, perceptions, behaviors, and practices regarding dengue.

- Positive deviance inquiry

The PD inquiry helped identify the PD role models from the FGDs and their local, accessible, and replicable strategies regarding dengue prevention and control. The PD behaviors were validated by observing the households to confirm the role models. A total of six role models-two male and four female community members-were identified. The role models and their family members had never been infected by dengue and were following the positive behaviors related to dengue prevention and control during the observation visits made by the data collectors (Table 1, examples of identified PD behaviors). 
Table 1. Positive deviant behaviors identified during the PD process in Islamabad 3.

\begin{tabular}{|c|c|}
\hline Desired Behaviors & Positive Deviance Behaviors \\
\hline \multirow{2}{*}{ Knowledge } & Correct knowledge of the dengue vector and mosquito biting time \\
\hline & Knowledge of dengue mosquito's breeding places inside and outside the house \\
\hline Avoid water storage & $\begin{array}{l}\text { A housewife does not store water. She uses it immediately so that the dengue } \\
\text { mosquitoes do not breed in the clean water }\end{array}$ \\
\hline Change the water in plants & $\begin{array}{c}\text { A housewife changes the water in her plants every day to ensure no mosquitoes } \\
\text { breed inside the plants }\end{array}$ \\
\hline Cover the water containers & $\begin{array}{l}\text { A housewife covers all the water tanks and water containers to avoid mosquito } \\
\text { breeding }\end{array}$ \\
\hline \multirow{2}{*}{ Clean the water tank } & $\begin{array}{l}\text { A male community member covers his water tank and cleans it on regular basis to } \\
\text { avoid any mosquito breeding }\end{array}$ \\
\hline & $\begin{array}{l}\text { A female community member cleans her water tank with a brush and soap twice a } \\
\text { week to avoid mosquito breeding }\end{array}$ \\
\hline Bury the old bottles and tins & $\begin{array}{l}\text { A housewife collects the old bottles and tins and buries them outside the house to } \\
\text { avoid mosquitoes breeding in them }\end{array}$ \\
\hline Clean the tray under refrigerator & $\begin{array}{l}\text { A female community member cleans the tray which lies under the refrigerators to } \\
\text { avoid the breeding of mosquitoes in it }\end{array}$ \\
\hline Change the water in the water cooler fan & $\begin{array}{l}\text { A female community member changes the water in her watercooler fan on daily } \\
\text { basis to avoid mosquito growth inside it }\end{array}$ \\
\hline Healthcare seeking & $\begin{array}{l}\text { A female community member knows the signs and symptoms of dengue fever and } \\
\text { seeks treatment as soon as she suspects dengue }\end{array}$ \\
\hline \multirow{3}{*}{ Personal protection } & $\begin{array}{l}\text { A mother ensures that her children wear full-sleeved clothes during the day to } \\
\text { avoid mosquito bites }\end{array}$ \\
\hline & $\begin{array}{l}\text { A mother keeps her children sleeping under bed net during the day to avoid } \\
\text { mosquito bites }\end{array}$ \\
\hline & $\begin{array}{l}\text { A father ensures that his children wear long-sleeved clothes to avoid mosquito } \\
\text { bites during the day }\end{array}$ \\
\hline
\end{tabular}

- Community feedback session and action planning

After the PD behaviors were identified, a community feedback session was conducted at the end of the one-week PD process. The purpose of this activity was to review the PD findings with a larger audience, share and vet the PD behaviors and encourage community members to adopt these behaviors. The PD behaviors were interactively shared with the community using a cardboard box house representing the PD house. The PD behaviors were written on flip charts (large papers) with colorful sketches and inserted into the cardboard box house. The community members were invited one by one to take out the paper and read the behavior. After sharing the PD behaviors, a simple action plan was developed to explore ways to enable other community members to follow these simple behaviors (Figure S2, Role models share their PD behaviors during the feedback session).

\subsubsection{Phase 2. Positive Deviance Intervention (2 Months)}

Phase 2 was the implementation of the PD-informed study for 2 months in the intervention area. The following activities were carried out in the PD implementation phase:

- Training of volunteers and IEC materials development

A one-day interactive training session was organized with the selected volunteers at the church of the Faisal colony. A total of 20 volunteers participated in the training. Participatory techniques such as brainstorming, group discussions, role plays, and conceptual games were used during the training sessions. Half of the training was allocated for the development of local sketches of the identified PD behaviors to be used in the 
local information, education, and communication (IEC) materials. After completion of the exercise, the best sketch was used in the IEC material to reinforce the key messages.

- Interactive PD sessions

PD sessions were organized by the trained volunteers in the intervention group on a weekly basis. The PD role models were also present in the PD sessions and shared their local, simple behaviors and strategies to avoid dengue, which served as social proof for the other community members. Role plays, storytelling, and locally made IEC materials were used in these sessions. On average, 20 persons participated in each session (Figure S3, PD health education session with female community members).

\section{- PD Seminar}

An interactive advocacy event was organized after 6 weeks of intervention implementation. The main objective of the seminar was to acknowledge the volunteers, reinforce the key messages, and celebrate their achievements. The PD seminar was attended by most of the community members from the intervention group. The community was involved in the preparations at least one week before the seminar. The following were the main activities of the PD seminar:

Illustration competition

A sketch competition was organized to reinforce the dengue prevention and control messages. Communities were informed about the sketch competition at least one week in advance with instructions on how to prepare the dengue sketches. These colorful sketches were displayed at the seminar venue. The audience went through all the pictures and reviewed the messages on each sketch. The three best sketches were selected for the prizes (Figure S4, an illustration made by community member for the sketch competition).

Quiz competition

A quiz competition was organized during the seminar. Key questions regarding dengue were written on small pieces of paper, wrapped, and put in a basket. The seminar audience was actively engaged in the quiz competition. On giving the correct answer, the person received a small souvenir such as a bar of soap. The purpose of this segment was to reinforce the dengue messages in an interesting and engaging manner.

\section{Results}

\subsection{Sociodemographics at the Baseline}

A total of 112 participants were recruited for the study: 56 for the intervention group and 56 for the control group at baseline. At the midline (after two months) and endline (after four months), the number of participants in the control group decreased by two.

At the baseline, there were no statistically significant differences found in sociodemographic characteristics such as sex, age, marital status, religion, education, occupation, and average monthly income between intervention and control groups (Table 2).

\subsection{Dengue Knowledge at Baseline}

An equal number of respondents in the control and intervention groups knew that dengue is mosquito-transmitted $(67.9 \%)$. There was a statistically significant difference in knowledge of three or more dengue symptoms between groups at the baseline where $53.6 \%$ of respondents from the intervention group knew three or more symptoms compared to $19.6 \%$ of respondents from the control group. However, no statistically significant differences were found between groups in terms of knowing about mosquito breeding sites and mosquito and dengue prevention methods. An independent sample t-test revealed that there were no statistically significant differences between the intervention and control group at the baseline in the total knowledge score, as well as in the total attitude and practice scores (Table 3). 
Table 2. Sociodemographic characteristics of the intervention and control groups surveyed (baseline).

\begin{tabular}{|c|c|c|c|c|c|}
\hline \multirow{2}{*}{$\begin{array}{l}\text { Characteristics } \\
(\mathrm{N}=112)\end{array}$} & \multicolumn{2}{|c|}{ Intervention Group } & \multicolumn{2}{|c|}{ Control Group } & \multirow[b]{2}{*}{$p$-Value * } \\
\hline & n (\%) & Median (Range) & n (\%) & Median (Range) & \\
\hline \multicolumn{6}{|l|}{ Sex } \\
\hline Female & $47(83.9)$ & - & $42(75.0)$ & - & \multirow[b]{2}{*}{1.000} \\
\hline Male & $9(16.1)$ & - & $14(25.0)$ & - & \\
\hline Age & & $31.0(18-58)$ & & $30.0(18-55)$ & \multirow[b]{3}{*}{0.789} \\
\hline$<30$ & $24(42.9)$ & $24.0(18-28)$ & $25(44.6)$ & $21.0(18-29)$ & \\
\hline$\geq 30$ & $32(57.1)$ & $35.5(30-58)$ & $31(55.4)$ & $37.0(30-55)$ & \\
\hline \multicolumn{6}{|l|}{ Marital status } \\
\hline Single & $15(26.8)$ & - & $13(23.2)$ & - & \multirow{3}{*}{1.000} \\
\hline Married & $41(73.2)$ & - & $43(76.8)$ & - & \\
\hline \multicolumn{5}{|l|}{ Religion } & \\
\hline Christian & $56(100)$ & - & $56(100)$ & - & \\
\hline \multicolumn{6}{|l|}{ Education } \\
\hline Primary school (1-5) & $5(8.9)$ & - & 7 (12.5) & - & \multirow{7}{*}{0.285} \\
\hline Secondary school (5-9) & $6(10.7)$ & - & $11(19.6)$ & - & \\
\hline High school (10) & $14(25.0)$ & - & $19(33.9)$ & - & \\
\hline Intermediate-FA & $5(8.9)$ & - & $3(5.4)$ & - & \\
\hline Bachelor-BA & $1(1.8)$ & - & $1(1.8)$ & - & \\
\hline Masters-MA & $0(0)$ & - & $2(3.6)$ & - & \\
\hline No formal education & $25(44.6)$ & - & $13(23.2)$ & - & \\
\hline \multicolumn{6}{|l|}{ Occupation } \\
\hline Unemployed & $15(26.8)$ & - & $15(26.8)$ & - & \multirow{6}{*}{0.114} \\
\hline Government job & $3(5.4)$ & - & $1(1.8)$ & - & \\
\hline Private job & $11(19.6)$ & - & $14(25.0)$ & - & \\
\hline Street vendor & $1(1.8)$ & - & $2(3.6)$ & - & \\
\hline Housewife & $24(42.9)$ & - & $24(42.9)$ & - & \\
\hline Others & $2(3.6)$ & - & $0(0)$ & - & \\
\hline \multicolumn{6}{|c|}{ Average monthly income (Rupees) } \\
\hline$<25,000$ & $36(64.3)$ & - & $31(55.4)$ & - & \multirow{5}{*}{0.896} \\
\hline $25,000-50,000$ & $11(19.6)$ & - & $16(28.6)$ & - & \\
\hline $50,000-75,000$ & $4(7.1)$ & - & $2(3.6)$ & - & \\
\hline$>100,000$ & $1(1.8)$ & - & $0(0)$ & - & \\
\hline Don't know & $4(7.1)$ & - & $7(12.5)$ & - & \\
\hline
\end{tabular}

${ }^{*} \chi^{2}$ test/Fisher's Exact test.

\subsection{Knowledge about Dengue at the Baseline, Midline, and Endline}

An improvement in knowledge over time was observed for almost all examined variables, even in the control group. At the baseline, $67.9 \%$ of respondents from the intervention and control group knew that dengue is mosquito-transmitted compared to $100 \%$ of respondents from the intervention group and $83.3 \%$ of respondents from the control group at the endline. At the endline, $96.4 \%$ of respondents from the intervention and $64.8 \%$ of respondents from the control group knew that dengue mosquitoes most often bite during the day, compared to $26.8 \%$ of respondents from the intervention group and $17.9 \%$ of respondents from the control group at the baseline. Furthermore, $53.6 \%$ of respondents from the intervention and $19.6 \%$ of respondents from the control group knew three or more dengue symptoms at the baseline, compared to $96.4 \%$ of respondents from the intervention group and $70.4 \%$ of respondents from the control group at the endline (Table 4). 
Table 3. Dengue knowledge, attitudes, and practice based on intervention and control groups (baseline). " $\mathrm{n}$ " indicates the number of persons that answered 'yes' to the question).

\begin{tabular}{|c|c|c|c|c|c|}
\hline & $\mathbf{n}$ & $\%$ & $\mathbf{n}$ & $\%$ & \\
\hline Baseline & \multicolumn{2}{|c|}{$\begin{array}{l}\text { Intervention Group } \\
\qquad(\mathrm{n}=56)\end{array}$} & \multicolumn{2}{|c|}{$\begin{array}{l}\text { Control Group } \\
\quad(n=56)\end{array}$} & $p$-Value \\
\hline & & & & & \\
\hline Dengue is mosquito-transmitted & 38 & 67.9 & 38 & 67.9 & $1.000 *$ \\
\hline Knows 3 or more dengue symptoms & 30 & 53.6 & 11 & 19.6 & $p<0.001$ * \\
\hline Knows 1 or more mosquito breeding sites inside the house & 47 & 83.9 & 44 & 78.6 & $0.629 *$ \\
\hline Knows 1 or more mosquito breeding sites outside the house & 45 & 80.4 & 44 & 78.6 & $1.000 *$ \\
\hline Knows 1 or more mosquito breeding prevention methods & 48 & 85.7 & 50 & 89.3 & $0.776^{*}$ \\
\hline Knows 1 or more dengue prevention methods & 52 & 92.9 & 52 & 92.9 & $1.000 *$ \\
\hline $\begin{array}{l}\text { Total knowledge score } \\
\qquad(0-48)\end{array}$ & $\begin{array}{l}\text { Mean } \\
10.09\end{array}$ & $\begin{array}{c}\mathrm{SD} \\
3.549\end{array}$ & $\begin{array}{l}\text { Mean } \\
8.91\end{array}$ & $\begin{array}{c}\mathrm{SD} \\
3.053\end{array}$ & 0.062 ** \\
\hline $\begin{array}{c}\text { Attitude } \\
\text { Total attitude score } \\
(0-32)\end{array}$ & $\begin{array}{l}\text { Mean } \\
24.21\end{array}$ & $\begin{array}{c}\text { SD } \\
3.329\end{array}$ & $\begin{array}{l}\text { Mean } \\
24.55\end{array}$ & $\begin{array}{c}\text { SD } \\
4.004\end{array}$ & $0.627^{* *}$ \\
\hline $\begin{array}{c}\text { Practice } \\
\text { Total practice score } \\
(0-24)\end{array}$ & $\begin{array}{l}\text { Mean } \\
10.21\end{array}$ & $\begin{array}{c}\mathrm{SD} \\
1.615\end{array}$ & $\begin{array}{l}\text { Mean } \\
10.63\end{array}$ & $\begin{array}{l}\mathrm{SD} \\
1.169\end{array}$ & $0.156^{* *}$ \\
\hline
\end{tabular}

${ }^{*} \chi^{2}$ test; ${ }^{* *}$ Independent samples $t$-test.

Table 4. Knowledge about dengue transmission, prevention practice, and symptoms at the baseline, midline, and endline. ' $\mathrm{I}$ ' means intervention group and ' $\mathrm{C}$ ' means control group.

\begin{tabular}{|c|c|c|c|c|c|c|}
\hline \multirow{2}{*}{ Knowledge } & \multicolumn{2}{|c|}{$\begin{array}{l}\text { Baseline } \\
\text { n (\%) }\end{array}$} & \multicolumn{2}{|c|}{$\begin{array}{l}\text { Midline } \\
\text { n (\%) }\end{array}$} & \multicolumn{2}{|c|}{$\begin{array}{l}\text { Endline } \\
\text { n (\%) }\end{array}$} \\
\hline & I Group & C Group & I Group & C Group & I Group & C Group \\
\hline \multicolumn{7}{|l|}{ How is dengue transmitted? } \\
\hline Mosquito & $38(67.9)$ & $38(67.9)$ & $56(100)$ & $44(81.5)$ & $56(100)$ & $45(83.3)$ \\
\hline \multicolumn{7}{|c|}{ What type of mosquito causes dengue fever? } \\
\hline Aedes & $5(8.9)$ & $6(10.7)$ & $38(67.9)$ & $20(37)$ & $50(89.3)$ & $31(57.4)$ \\
\hline \multicolumn{7}{|c|}{ When do dengue mosquitoes most often bite? } \\
\hline Bite during the day & $15(26.8)$ & $10(17.9)$ & $49(87.5)$ & $19(35.2)$ & $54(96.4)$ & $35(64.8)$ \\
\hline Bite during the night time & $25(44.6)$ & $34(60.7)$ & $7(12.5)$ & $29(53.7)$ & $2(3.6)$ & $19(35.2)$ \\
\hline Other & $2(3.6)$ & $0(0)$ & $0(0)$ & $0(0)$ & $0(0)$ & $0(0)$ \\
\hline Don't know & $14(25)$ & $12(21.4)$ & $0(0)$ & $6(11.1)$ & $0(0)$ & $0(0)$ \\
\hline \multicolumn{7}{|c|}{ Where do Aedes mosquitoes usually breed inside the house? } \\
\hline In the trays under the fridge & $3(5.4)$ & $1(1.8)$ & $6(10.7)$ & $3(5.6)$ & $8(14.3)$ & $5(9.3)$ \\
\hline In the flower pot trays & $2(3.6)$ & $1(1.8)$ & $7(12.5)$ & $2(3.7)$ & $9(16.1)$ & $2(3.7)$ \\
\hline In the water containers & $35(62.5)$ & $22(39.3)$ & $30(53.6)$ & $35(64.8)$ & $31(55.4)$ & $18(33.3)$ \\
\hline In the open water tanks & $8(14.3)$ & $22(39.3)$ & $30(53.6)$ & $16(29.6)$ & $34(60.7)$ & $34(63)$ \\
\hline Dirty environment & $2(3.6)$ & $1(1.8)$ & $1(1.8)$ & $0(0)$ & $0(0)$ & $0(0)$ \\
\hline Don't know & $6(10.7)$ & $11(19.6)$ & $0(0)$ & $7(13)$ & $0(0)$ & $3(5.6)$ \\
\hline $\begin{array}{l}\text { Knows } 1 \text { or more breeding sites } \\
\text { inside the house }\end{array}$ & 47 (83.9) & $44(78.6)$ & $54(96.4)$ & $47(87)$ & $55(98.2)$ & $51(94.4)$ \\
\hline \multicolumn{7}{|c|}{ Where do Aedes mosquitoes usually breed outside the house? } \\
\hline In the flower leaves & $9(16.1)$ & $15(26.8)$ & $14(25)$ & $12(22.2)$ & $19(33.9)$ & $8(14.8)$ \\
\hline In the old tires & $6(10.7)$ & $1(1.8)$ & $13(23.2)$ & $4(7.4)$ & $20(35.7)$ & $1(1.9)$ \\
\hline In the roof gutter & $12(21.4)$ & $5(8.9)$ & $17(30.4)$ & $10(18.5)$ & $11(19.6)$ & $3(5.6)$ \\
\hline In the empty cans, shells & $22(39.3)$ & $27(48.2)$ & $38(67.9)$ & $23(42.6)$ & $51(91.1)$ & $43(79.6)$ \\
\hline Dirty water & $2(3.6)$ & $0(0)$ & $0(0)$ & $0(0)$ & $0(0)$ & $0(0)$ \\
\hline Don't know & $9(16.1)$ & $11(19.6)$ & $1(1.8)$ & $14(25.9)$ & $0(0)$ & $3(5.6)$ \\
\hline $\begin{array}{c}\text { Knows } 1 \text { or more breeding sites } \\
\text { outside the house }\end{array}$ & $45(80.4)$ & 44 (78.6) & $54(96.4)$ & $40(74.1)$ & $56(100)$ & $51(94.4)$ \\
\hline
\end{tabular}


Table 4. Cont.

\begin{tabular}{|c|c|c|c|c|c|c|}
\hline \multirow{2}{*}{ Knowledge } & \multicolumn{2}{|c|}{$\begin{array}{l}\text { Baseline } \\
\text { n (\%) }\end{array}$} & \multicolumn{2}{|c|}{$\begin{array}{l}\text { Midline } \\
\text { n (\%) }\end{array}$} & \multicolumn{2}{|c|}{$\begin{array}{l}\text { Endline } \\
\text { n (\%) }\end{array}$} \\
\hline & I Group & C Group & I Group & C Group & I Group & C Group \\
\hline \multicolumn{7}{|c|}{ How can you prevent mosquitoes from breeding? } \\
\hline Using insecticide in water & $9(16.1)$ & $12(21.4)$ & $31(55.4)$ & $14(25.9)$ & $35(62.5)$ & $16(29.6)$ \\
\hline $\begin{array}{l}\text { Changing stored water } \\
\text { frequently }\end{array}$ & $7(12.5)$ & $11(19.6)$ & $24(42.9)$ & $15(27.8)$ & $28(50)$ & $13(24.1)$ \\
\hline Turning containers upside down & $10(17.9)$ & $21(37.5)$ & $31(55.4)$ & $20(37)$ & $40(71.4)$ & $17(31.5)$ \\
\hline Putting covers on water jars & $27(48.2)$ & $20(35.7)$ & $45(80.4)$ & $28(51.9)$ & $34(60.7)$ & $22(40.7)$ \\
\hline $\begin{array}{c}\text { Burning or burying empty cans, } \\
\text { shells }\end{array}$ & $3(5.4)$ & $3(5.4)$ & $14(25)$ & $7(13)$ & $23(41.1)$ & $10(18.5)$ \\
\hline Spraying insecticide & $14(25)$ & $11(19.6)$ & $15(26.8)$ & $10(18.5)$ & $33(58.9)$ & $20(37)$ \\
\hline Clean the household & $7(12.5)$ & $3(5.4)$ & $0(0)$ & $0(0)$ & $0(0)$ & $0(0)$ \\
\hline Don't know & $3(5.4)$ & $2(3.6)$ & $2(3.6)$ & $3(5.6)$ & $0(0)$ & $0(0)$ \\
\hline $\begin{array}{l}\text { Knows } 1 \text { or more mosquito } \\
\text { breeding prevention methods }\end{array}$ & 48 (85.7) & $50(89.3)$ & $55(98.2)$ & $51(94.4)$ & $56(100)$ & $54(100)$ \\
\hline \multicolumn{7}{|c|}{ How can you prevent dengue? } \\
\hline Use mosquito net during the day & $5(8.9)$ & $9(16.1)$ & $15(26.8)$ & $14(25.9)$ & $22(39.3)$ & $9(16.7)$ \\
\hline Wear long sleeves/long pants & $23(41.1)$ & $22(39.3)$ & $48(85.7)$ & $37(68.5)$ & $52(92.9)$ & $42(77.8)$ \\
\hline Use mosquito repellent & $15(26.8)$ & $22(39.3)$ & $22(39.3)$ & $26(48.1)$ & $33(58.9)$ & $22(40.7)$ \\
\hline Use insecticide spray & $34(60.7)$ & $36(64.3)$ & $27(48.2)$ & $31(57.4)$ & $41(73.2)$ & $32(59.3)$ \\
\hline Cut down bushes near the house & $1(1.8)$ & $1(1.8)$ & $6(10.7)$ & $2(3.7)$ & $14(25)$ & $6(11.1)$ \\
\hline $\begin{array}{l}\text { Have children play far from } \\
\text { mosquito breeding area }\end{array}$ & $3(5.4)$ & $0(0)$ & $3(5.4)$ & $0(0)$ & $14(25)$ & $1(1.9)$ \\
\hline $\begin{array}{c}\text { Use mosquito coils during the } \\
\text { day }\end{array}$ & $4(7.1)$ & $3(5.4)$ & $9(16.1)$ & $2(3.7)$ & $21(37.5)$ & $3(5.6)$ \\
\hline $\begin{array}{c}\text { Keep household environment } \\
\text { clean }\end{array}$ & $4(7.1)$ & $0(0)$ & $4(7.1)$ & $4(7.4)$ & $26(46.4)$ & $12(22.2)$ \\
\hline $\begin{array}{l}\text { Install screens on } \\
\text { windows/doors }\end{array}$ & $1(1.8)$ & $0(0)$ & $1(1.8)$ & $0(0)$ & $16(28.6)$ & $1(1.9)$ \\
\hline Keep clothes tidy & $0(0)$ & $0(0)$ & $0(0)$ & $0(0)$ & $18(32.1)$ & $2(3.7)$ \\
\hline Use fan & $0(0)$ & $0(0)$ & $0(0)$ & $0(0)$ & $2(3.6)$ & $1(1.9)$ \\
\hline Don't know & $4(7.1)$ & $2(3.6)$ & $1(1.8)$ & $2(3.7)$ & $0(0)$ & $1(1.9)$ \\
\hline $\begin{array}{l}\text { Knows } 1 \text { or more dengue } \\
\text { prevention methods }\end{array}$ & $52(92.9)$ & $52(92.9)$ & $55(98.2)$ & $52(96.3)$ & $56(100)$ & $53(98.1)$ \\
\hline \multicolumn{7}{|c|}{ What are the symptoms of dengue? } \\
\hline High fever & $40(70.1)$ & $37(66.1)$ & $52(92.9)$ & $42(77.8)$ & $55(98.2)$ & $45(83.3)$ \\
\hline Headache & $16(28.6)$ & $12(21.4)$ & $34(60.7)$ & $26(48.1)$ & $45(80.4)$ & $29(53.7)$ \\
\hline Chills & $5(8.9)$ & $0(0)$ & $24(42.9)$ & $14(25.9)$ & $35(62.5)$ & $17(31.5)$ \\
\hline Nausea/Vomiting & $12(21.4)$ & $4(7.1)$ & $31(55.4)$ & $17(31.5)$ & $36(64.3)$ & $19(35.2)$ \\
\hline Rash & $13(23.2)$ & $3(5.4)$ & $24(42.9)$ & $9(16.7)$ & $22(39.3)$ & $7(13)$ \\
\hline Muscle and joint pain & $11(19.6)$ & $11(19.6)$ & $26(46.4)$ & $16(29.6)$ & $37(66.1)$ & $15(27.8)$ \\
\hline Bleeding & $6(10.7)$ & $2(3.6)$ & $25(44.6)$ & $7(13)$ & $35(62.5)$ & $12(22.2)$ \\
\hline Diarrhea & $0(0)$ & $0(0)$ & $5(8.9)$ & $1(1.9)$ & $1(1.8)$ & $0(0)$ \\
\hline Eye pain & $3(5.4)$ & $0(0)$ & $12(21.4)$ & $2(3.7)$ & $25(44.6)$ & $1(1.9)$ \\
\hline Don't know & $12(21.4)$ & $18(32.1)$ & $3(5.4)$ & $9(16.7)$ & $0(0)$ & $7(13)$ \\
\hline
\end{tabular}

\subsection{Knowledge Score Comparison between Intervention vs. Control Groups}

Results showed that there was a significant main effect of time $(F(1.74,187.94)=88.492$, $p<0.001, \eta p 2=0.450)$ and group $(\mathrm{F}(1,108)=81.518, p<0.001, \eta p 2=0.430)$, on knowledge scores. In addition, there was a significant interaction between group and time $(\mathrm{F}(1.74,187.94)$ $=19.037, p<0.001, \eta p 2=0.150$ ). For the pairwise comparisons, Bonferroni-adjusted paired t-tests were performed. Statistically significant differences in dengue knowledge between the control $(\mathrm{M}=8.93, \mathrm{SD}=3.107)$ and intervention $(\mathrm{M}=10.09, \mathrm{SD}=3.549)$ group were not found at the baseline $(p=0.071)$. After two months of the positive deviance intervention, the intervention group $(\mathrm{M}=19.00, \mathrm{SD}=6.093)$ had a better statistically significant improvement regarding dengue knowledge compared to the control group $(\mathrm{M}=13.13, \mathrm{SD}=4.953)$ 
$(p<0.001)$. Furthermore, after another two months at the end line, knowledge regarding dengue transmission, prevention practice, and symptoms not only persisted but continued to improve with statistically significant differences between the control group $(\mathrm{M}=14.30$, $\mathrm{SD}=4.944)$ and intervention group $(\mathrm{M}=25.00, \mathrm{SD}=9.607)(p<0.001)$. Estimated marginal means are visualized in the profile plot, where an increase in knowledge over time can be seen in both groups, especially in the intervention group (Figure 1.).

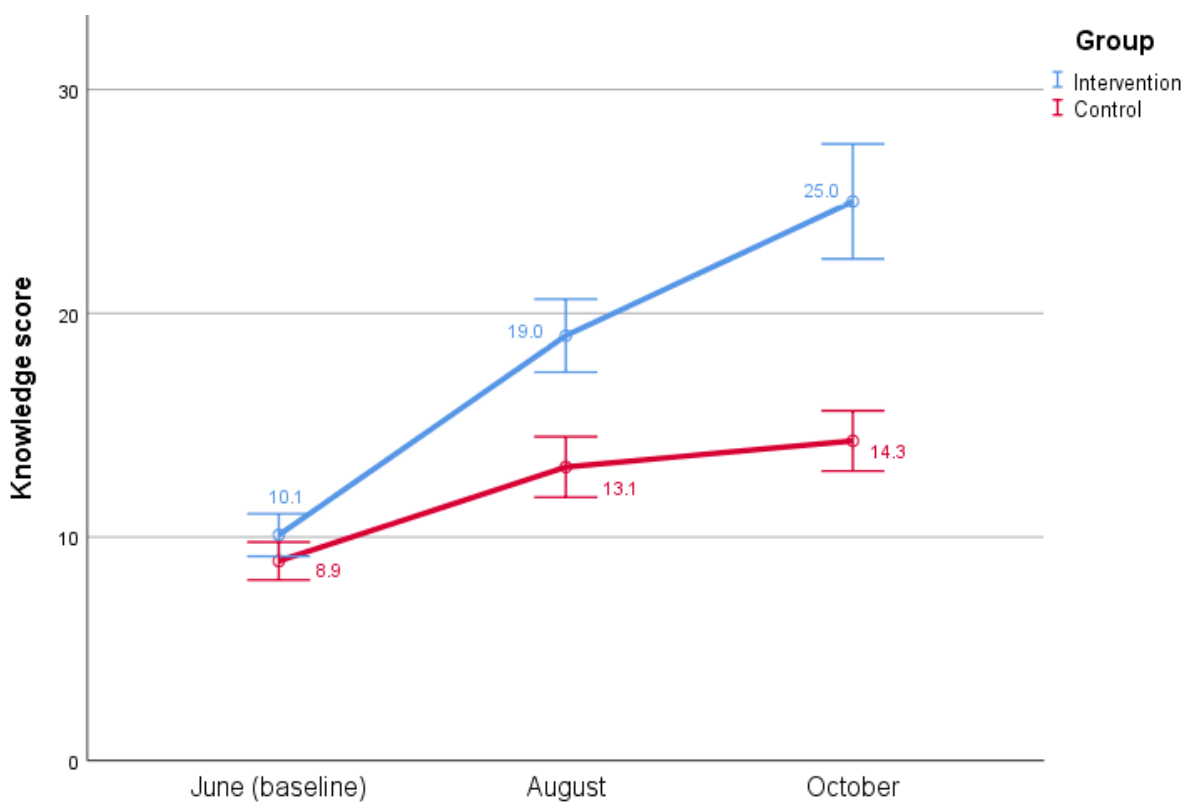

Figure 1. Change in mean dengue knowledge scores during three different times in 2020 in two low-income communities in Islamabad. Maximum knowledge score was 48 .

\subsection{Attitude towards Dengue at Baseline, Midline, and Endline}

Attitude towards dengue was good overall among the respondents from the intervention and control groups. The vast majority of respondents from both groups agreed that dengue is a serious infection, that removing empty containers can protect from dengue infection, that using bed nets, repellents, and long sleeves can protect from mosquito bites, and that communities should participate in controlling dengue (Table 5).

\subsection{Attitude Scores Comparison between Intervention and Control Groups}

Results showed that there was a significant main effect of time $(\mathrm{F}(2,216)=25.431$, $p<0.001, \eta p 2=0.191)$ and a non-significant main effect of group $(\mathrm{F}(1,108)=0.538, p=0.465$, $\eta \mathrm{p} 2=0.005)$, on attitude scores. There was a significant interaction between group and time $(\mathrm{F}(2,216)=4.577, p=0.011, \eta \mathrm{p} 2=0.041)$. For the pairwise comparisons, Bonferroniadjusted paired t-tests were performed. Statistically significant differences in dengue attitude between the control group $(\mathrm{M}=24.52, \mathrm{SD}=4.064)$ and intervention $(\mathrm{M}=24.21$, $\mathrm{SD}=3.329)$ group were not found at the baseline $(p=0.668)$. Furthermore, at the midline, after two months and positive deviance intervention, statistically significant differences in dengue attitude between the control group $(\mathrm{M}=26.39, \mathrm{SD}=2.695)$ and intervention $(\mathrm{M}=25.84, \mathrm{SD}=2.492)$ group were also not found $(p=0.269)$. After another two months at the end line, attitudes towards dengue improved significantly in the intervention group $(\mathrm{M}=28.34, \mathrm{SD}=3.604)$ compared to the control group $(\mathrm{M}=26.52, \mathrm{SD}=4.343)(p=0.018)$.

Estimated marginal means of dengue attitudes are visualized in the profile plot, where an increase in dengue attitudes between baseline and midline for the intervention and control group is quite similar, but between midline and end line, control-group attitudes remain almost horizontal compared to increased intervention-group attitudes (Figure 2). 
Table 5. Attitude towards dengue disease at the baseline, midline, and endline.

\begin{tabular}{lcccccc}
\hline \multirow{2}{*}{ Attitude } & \multicolumn{2}{c}{$\begin{array}{c}\text { Agree } \\
\text { n (\%) }\end{array}$} & \multicolumn{2}{c}{$\begin{array}{c}\text { Don't Know } \\
\text { n (\%) }\end{array}$} & \multicolumn{2}{c}{$\begin{array}{c}\text { Disagree } \\
\text { n (\%) }\end{array}$} \\
\cline { 2 - 7 } & I Group & C Group & I Group & C Group & I Group & C Group \\
\hline \multicolumn{7}{c}{ I Dengue is a serious illness? } \\
\hline Baseline & $56(100)$ & $53(94.6)$ & $0(0)$ & $0(0)$ & $0(0)$ & $3(5.4)$ \\
Midline & $55(98.2)$ & $54(100)$ & $0(0)$ & $0(0)$ & $1(1.8)$ & $0(0)$ \\
Endline & $56(100)$ & $51(94.4)$ & $0(0)$ & $1(1.9)$ & $0(0)$ & $2(3.7)$ \\
Baseline & $47(83.9)$ & $39(69.6)$ & $0(0)$ & $2(3.6)$ & $9(16.1)$ & $15(26.8)$ \\
Midline & $50(89.3)$ & $46(85.2)$ & $0((0)$ & $1(1.9)$ & $6(10.7)$ & $7(13)$ \\
Endline & $51(91.1)$ & $44(81.5)$ & $0(0)$ & $0(0)$ & $5(8.9)$ & $10(18.5)$ \\
Baseline & $37(66.1)$ & $40(71.4)$ & $7(12.5)$ & $6(10.7)$ & $12(21.4)$ & $10(17.9)$ \\
Midline & $49(87.5)$ & $37(68.5)$ & $2(3.6)$ & $3(5.6)$ & $5(8.9)$ & $14(25.9)$ \\
Endline & $46(82.1)$ & $38(70.4)$ & $4(7.1)$ & $5(9.3)$ & $6(10.7)$ & $11(20.4)$ \\
Baseline & $34(60.7)$ & $39(69.6)$ & $1(1.8)$ & $0(0)$ & $21(37.5)$ & $17(30.4)$ \\
Midline & $44(78.6)$ & $40(74.1)$ & $0(0)$ & $2(3.7)$ & $12(21.4)$ & $12(22.2)$ \\
Endline & $47(83.9)$ & $34(63)$ & $0(0)$ & $0(0)$ & $9(16.1)$ & $20(37)$ \\
& Can removing empty containers protect you from dengue infection? & \\
Baseline & $49(87.5)$ & $48(85.7)$ & $0(0)$ & $1(1.8)$ & $7(12.5)$ & $7(12.5)$ \\
Midline & $56(100)$ & $54(100)$ & $0(0)$ & $0(0)$ & $0(0)$ & $0(0)$ \\
Endline & $55(98.2)$ & $52(96.3)$ & $0(0)$ & $0(0)$ & $1(1.8)$ & $2(3.7)$ \\
Baseline & $55(98.2)$ & $54(96.4)$ & $0(0)$ & $0(0)$ & $1(1.8)$ & $2(3.6)$ \\
Midline & $56(100)$ & $53(98.1)$ & $0(0)$ & $0(0)$ & $0(0)$ & $1(1.9)$ \\
Endline & $56(100)$ & $52(96.3)$ & $0(0)$ & $0(0)$ & $0(0)$ & $2(3.7)$ \\
\hline
\end{tabular}

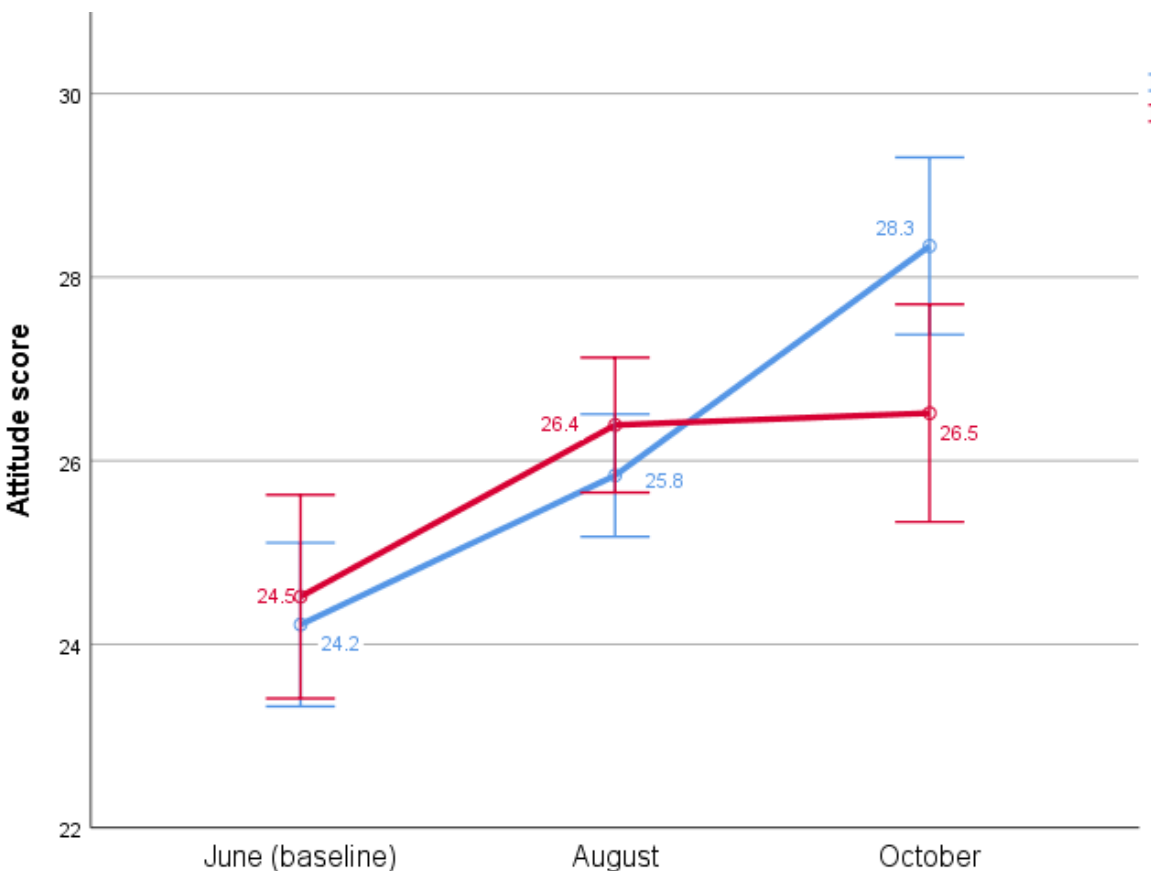

Group

Figure 2. Change in mean dengue attitude scores during three different times in 2020 in two lowincome communities in Islamabad. Maximum attitude score was 32.

\subsection{Dengue Prevention and Control Practices at Baseline, Midline and Endline}

At the endline, an improvement in practice was observed related to dengue preventive methods, especially in the intervention group, such as sleeping under a bed net during the 
day, using insecticide spray, repellent, mosquito coil, and smoke to drive away mosquitoes. At the endline, $53.6 \%$ of respondents from the intervention group were covering all water containers, compared to $10.7 \%$ at the baseline. At the endline, $55.4 \%$ of respondents from the intervention group were changing the storage water once a week compared to $25 \%$ at the baseline. Interestingly, an improvement in practice was observed not only in the intervention group but also in the control group (Table 6).

Table 6. Dengue practice at the baseline, midline, and endline.

\begin{tabular}{|c|c|c|c|c|c|c|}
\hline \multirow{2}{*}{ Practice } & \multicolumn{2}{|c|}{$\begin{array}{l}\text { Baseline } \\
\text { n (\%) }\end{array}$} & \multicolumn{2}{|c|}{$\begin{array}{l}\text { Midline } \\
\text { n (\%) }\end{array}$} & \multicolumn{2}{|c|}{$\begin{array}{l}\text { Endline } \\
\text { n (\%) }\end{array}$} \\
\hline & I Group & C Group & I Group & C Group & I Group & C Group \\
\hline \multicolumn{7}{|c|}{ What do you do to prevent dengue? } \\
\hline Nothing & $2(3.6)$ & $7(12.5)$ & $3(5.4)$ & $2(3.7)$ & $4(7.1)$ & $0(0)$ \\
\hline Sleep under bed net during the day & $9(16.1)$ & $16(28.6)$ & $15(26.8)$ & $22(40.7)$ & $29(51.8)$ & $18(33.3)$ \\
\hline Use fan to prevent mosquito bites & $9(16.1)$ & $17(30.4)$ & $10(17.9)$ & $22(40.7)$ & $17(30.4)$ & $10(18.5)$ \\
\hline Use insecticide spray & $40(71.4)$ & $41(73.2)$ & $47(83.9)$ & $41(75.9)$ & $53(94.6)$ & 49 (90.7) \\
\hline Use repellent & $30(53.6)$ & $26(46.4)$ & $47(83.9)$ & $38(70.4)$ & $51(91.1)$ & $32(59.3)$ \\
\hline Use mosquito coil & $25(44.6)$ & $22(39.3)$ & $42(75)$ & $28(51.9)$ & $51(91.1)$ & $30(55.6)$ \\
\hline Use smoke to drive away mosquitoes & $5(8.9)$ & $1(1.8)$ & $8(14.3)$ & $5(9.3)$ & $13(23.2)$ & $2(3.7)$ \\
\hline Cover all water containers & $6(10.7)$ & $3(5.4)$ & $21(37.5)$ & $6(11.1)$ & $30(53.6)$ & $15(27.8)$ \\
\hline $\begin{array}{c}\text { Change water in trays under the } \\
\text { fridge }\end{array}$ & $0(0)$ & $0(0)$ & 7 (12.5) & $0(0)$ & 11 (19.6) & $2(3.7)$ \\
\hline Destroy or burn unused containers & $1(1.8)$ & $0(0)$ & $3(5.4)$ & $0(0)$ & $18(32.1)$ & $2(3.7)$ \\
\hline \multicolumn{7}{|c|}{ Do you keep covers on the water containers in the home? } \\
\hline Yes & $55(98.2)$ & $54(96.4)$ & $56(100)$ & $53(98.1)$ & $56(100)$ & $54(100)$ \\
\hline \multicolumn{7}{|c|}{ Please can I observe some of the containers? } \\
\hline Covers observed on all containers & $45(80.4)$ & $44(78.6)$ & $51(91.1)$ & $48(88.9)$ & $53(94.6)$ & $53(98.1)$ \\
\hline Covers observed on some containers & $10(17.9)$ & $9(16.1)$ & $5(8.9)$ & $5(9.3)$ & $3(5.4)$ & $1(1.9)$ \\
\hline No covers observed & $1(1.8)$ & $3(5.4)$ & $0(0)$ & $1(1.9)$ & $0(0)$ & $0(0)$ \\
\hline \multicolumn{7}{|c|}{ How often do you change the storage water? } \\
\hline Once a week & $14(25)$ & $18(32.1)$ & $21(37.5)$ & $20(37)$ & $31(55.4)$ & $30(55.6)$ \\
\hline More than once a week & $34(60.7)$ & $37(66.1)$ & $31(55.4)$ & $34(63)$ & $24(42.9)$ & $22(40.7)$ \\
\hline Twice per month & $2(3.6)$ & $0(0)$ & $2(3.6)$ & $0(0)$ & $0(0)$ & $0(0)$ \\
\hline Once a month & $0(0)$ & $1(1.8)$ & $2(3.6)$ & $0(0)$ & $1(1.8)$ & $2(3.7)$ \\
\hline Never & $4(7.1)$ & $0(0)$ & $0(0)$ & $0(0)$ & $0(0)$ & $0(0)$ \\
\hline Don't know & $2(3.6)$ & $0(0)$ & $0(0)$ & $0(0)$ & $0(0)$ & $0(0)$ \\
\hline \multicolumn{7}{|c|}{ How often do you clean the water containers? } \\
\hline Every day & $43(76.8)$ & $44(78.6)$ & $45(80.4)$ & $43(79.6)$ & $35(62.5)$ & $36(66.7)$ \\
\hline Once a week & $8(14.3)$ & $9(16.1)$ & $10(17.9)$ & $11(20.4)$ & $20(35.7)$ & $10(18.5)$ \\
\hline Once a month & $4(7.1)$ & $2(3.6)$ & $0(0)$ & $0(0)$ & $0(0)$ & $8(14.8)$ \\
\hline Occasionally & $1(1.8)$ & $0(0)$ & $0(0)$ & $0(0)$ & $0(0)$ & $0(0)$ \\
\hline Never & $0(0)$ & $1(1.8)$ & $0(0)$ & $0(0)$ & $1(1.8)$ & $0(0)$ \\
\hline Don't know & $0(0)$ & $0(0)$ & $1(1.8)$ & $0(0)$ & $0(0)$ & $0(0)$ \\
\hline \multicolumn{7}{|c|}{ Observe water containers } \\
\hline Containers look very clean & $50(89.3)$ & $48(85.7)$ & $56(100)$ & $51(94.4)$ & $56(100)$ & $52(96.3)$ \\
\hline Containers do not look very clean & $6(10.7)$ & $8(14.3)$ & $0(0)$ & $3(5.6)$ & $0(0)$ & $2(3.7)$ \\
\hline \multicolumn{7}{|c|}{ What do you do with containers you are not currently using? } \\
\hline Leave them empty as they are & $4(7.1)$ & $3(5.4)$ & $3(5.4)$ & $6(11.1)$ & $2(3.6)$ & $0(0)$ \\
\hline Turn them upside down & $13(23.2)$ & $13(23.2)$ & $29(51.8)$ & $21(38.9)$ & $33(58.9)$ & $26(48.1)$ \\
\hline Move them inside & $12(21.4)$ & $23(41.1)$ & $17(30.4)$ & $12(22.2)$ & $15(26.8)$ & $12(22.2)$ \\
\hline Move them outside & $26(46.4)$ & $18(32.1)$ & $12(21.4)$ & $20(37)$ & $10(17.9)$ & $16(29.6)$ \\
\hline Don't have extra containers/Sell & $2(3.6)$ & $1(1.8)$ & $0(0)$ & $1(1.9)$ & $0(0)$ & $0(0)$ \\
\hline \multicolumn{7}{|c|}{ What do you do with waste such as old shells, cans, tires, plastic bottles, and other small containers? } \\
\hline Bury them & $1(1.8)$ & $0(0)$ & $0(0)$ & $0(0)$ & $0(0)$ & $0(0)$ \\
\hline Turn them upside down & $2(3.6)$ & $0(0)$ & $1(1.8)$ & $2(3.7)$ & $3(5.4)$ & $1(1.9)$ \\
\hline Burn them & $0(0)$ & $0(0)$ & $1(1.8)$ & $0(0)$ & $2(3.6)$ & $1(1.9)$ \\
\hline Move them outside & $52(92.9)$ & $54(96.4)$ & $55(98.2)$ & $52(96.3)$ & $52(92.9)$ & $52(96.3)$ \\
\hline Sell/Recycle & $6(10.7)$ & $3(5.4)$ & $0(0)$ & $0(0)$ & $1(1.8)$ & $0(0)$ \\
\hline
\end{tabular}




\subsection{Practice Score Comparison between Intervention and Control Groups}

Results showed that there was a significant main effect of time $(\mathrm{F}(2,216)=45.019$, $p<0.001, \eta p 2=0.294)$ and group $(\mathrm{F}(1,108)=20.070, p<0.001, \eta p 2=0.157)$, on practice scores. In addition, there was a significant interaction between group and time $(\mathrm{F}(2,216)=18.117, p<0.001, \eta p 2=0.144)$. For the pairwise comparisons, Bonferroniadjusted paired t-tests were performed. Statistically significant differences in dengue practice between the control group $(\mathrm{M}=10.57, \mathrm{SD}=1.159)$ and intervention $(\mathrm{M}=10.21$, $\mathrm{SD}=1.615)$ group were not found at the baseline $(p=0.184)$. Furthermore, at the midline, after two months and positive deviance intervention, statistically significant differences in dengue practice between the control group $(\mathrm{M}=11.44, \mathrm{SD}=1.525)$ and intervention $(\mathrm{M}=12.09, \mathrm{SD}=2.109)$ group were also not found $(p=0.070)$. After another two months at the endline, practice regarding dengue improved significantly in the intervention group $(\mathrm{M}=13.77, \mathrm{SD}=2.216)$ compared to the control group $(\mathrm{M}=11.37, \mathrm{SD}=1.629)(p<0.001)$ (Table 5).

The estimated marginal means of dengue practice are visualized in the profile plot, where an increase in dengue practice between baseline and midline is quite similar for the intervention and control group, but between midline and endline control-group practice remains almost horizontal, compared to increased intervention-group practice (Figure 3).

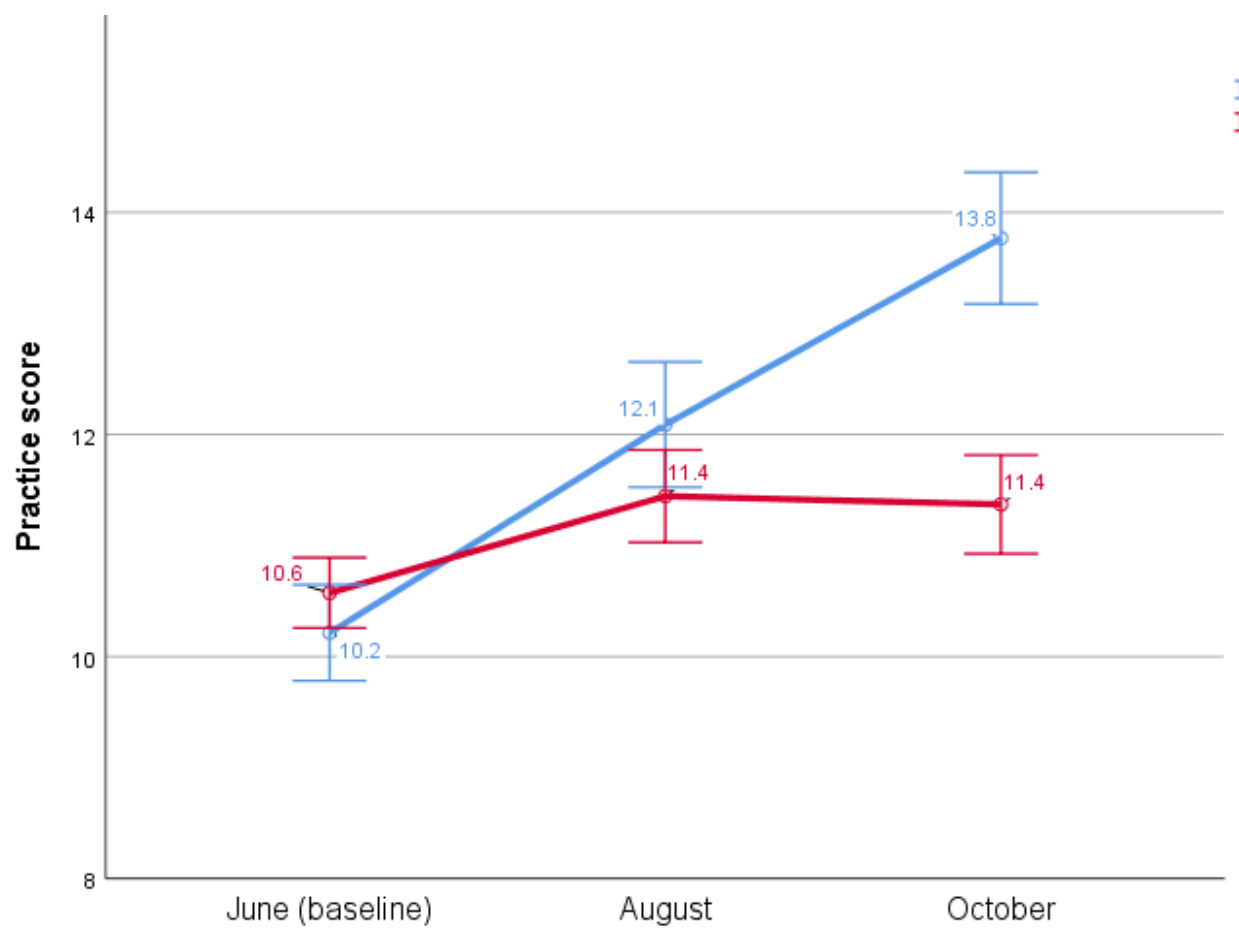

\section{Group}

I Intervention I Control

Figure 3. Change in mean dengue practice scores during three different times in 2020 in two lowincome communities in Islamabad. Maximum practice score was 24.

\section{Discussion}

To our knowledge, this is the first study that has applied and evaluated the positive deviance approach on dengue prevention and control. The study was aimed to determine the effectiveness of the PD approach on dengue prevention and control in the urban slums of Islamabad.

The study revealed that there were significant changes in the knowledge, attitudes, and practices in the intervention group compared to the control group. After two months of intervention, the intervention group demonstrated a statistically significant improvement in dengue knowledge compared to the control group. Furthermore, after another two months at the endline, knowledge regarding dengue transmission, prevention practices, 
and symptoms not only persisted but continued to improve, with statistically significant differences between the intervention and control group. Interestingly, there were also some improvements in knowledge in the control group, which could be attributed to the Directorate of Malaria Control Pakistan, which conducted health promotion activities in all the affected communities after the dengue outbreak. There could also be some possibilities of contamination, as some of the members of the intervention group were frequently visiting the control group area to meet their relatives.

After the first two months of intervention, there were no significant changes observed in attitudes and practices of the intervention communities. After another two months, the evaluation showed that there were significant changes in the attitudes and practices of the intervention community compared to the control community. The improvements in attitudes and practices in the intervention group can be attributed to the PD-informed behavior change intervention, which transformed knowledge into practices in the intervention group, which is validated by a behavior change intervention study conducted in Cambodia [38]. Despite the improvement in knowledge within the control group, no changes were observed in the attitudes and practices in the control group at the endline, which validated Park Lloyd's argument that knowledge alone is not enough to bring about positive changes in practices [39]. This further strengthens the notion that creating awareness alone is not sufficient unless the enabling environment is created through community participation at the household and community level for effective prevention and control of dengue [40]. Since the Alma Ata conference, community participation has been regarded as a vital element of primary healthcare programs by the World Health Organization [41]. However, unfortunately in most cases, participation remained expert-driven or top-down, where outsiders instructed communities on how to tackle the health or vector control problems [42]. It is uncommon that the community is considered as a partner and is engaged in the design, implementation, and evaluation of the health program.

In the PD study, the community was considered as an active partner, where they led the design and planning, and had a role in decision-making, which helped create interest, acceptance, and sustained community participation (no drop-out in intervention group) throughout the PD intervention, which is consistent with previous studies [20-22]. Equity and equality of participation were also taken seriously, ensuring that people from all segments of the community had equal opportunity to participate in the intervention [43]. The PD intervention was developed based on formative research understanding the normative behaviors around dengue. The PD inquiry (in-depth interviews) helped identify the already existent local, accessible, and easily replicable solutions which were promoted through actual role models to the other community members during the two months of intervention. The PD behaviors and messages were shared by the identified role models via storytelling, which served as social proof for the community members as they believed, "if he/she can do it, why can't I". The Information, Education, and Communication (IEC) materials were also developed by the community members using colorful sketches on flip charts (large paper) which had strong ownership of the communities. The previous studies also verified the fact that culturally sensitive and context-specific behavior change communication approaches were very effective at improving awareness and practices on dengue prevention and control $[17,38,43]$. Many randomized controlled trials also demonstrated positive outcomes in reducing entomological indicators, simply because the community was seriously engaged and the interventions were tailored to the local context $[23,44-46]$. The PD intervention was flexible, culturally appropriate, and led by the community. A similar study validated that a well-informed and context-appropriate intervention guarantees positive behavior changes [47].

The PD approach has tremendous potential as an effective behavior change and community engagement tool for dengue prevention and control. The approach has been very successful in engaging communities and received very positive feedback from a smallscale evaluation of a malaria study conducted in Cambodia [30]. The PD approach was wellreceived in the community and produced a significant amount of interest, motivation, and 
empowerment among participants, which in turn improved the dengue-related outcomes in the intervention community. The real promise of the approach is the signs of sustainability of the intervention, with the dengue prevention and control behaviors sustained after two months of the end of the intervention (in the intervention group).

Another key reason for the active participation of the community in the study was the community-based interactive activities, such as small competitions. For example, the community members were engaged in competitions to develop sketches/drawings or develop songs on those messages or behaviors they heard in the last two months. This generated great interest, as they involved their families and neighbors in the competition to come up with good drawings and songs, which in turn mobilized the community and reinforced dengue behaviors at the community level. Community members were acknowledged with some small souvenirs (worth 1 USD per souvenir) for their best drawings and songs in front of the large community, which boosted their confidence and maintained their motivation throughout the intervention. Therefore, as Atkinson's study discussed, small incentives such as souvenirs should be considered to enhance participation and motivation in the vector control programs [48].

\section{Limitations}

The study was conducted on a small scale due to scarce financial resources. As the study used quasi-experiments using convenience sampling methodology, the findings therefore cannot be generalized; however, the study still provides some excellent insights on the process and evaluation of the approach. As the study was conducted in slum areas, the findings may only be relevant to a similar context.

\section{Conclusions}

The findings revealed that the positive deviance study had a significant impact on dengue knowledge, attitudes, and practices in the target communities, even in the short span of the implementation period. The study recommends that well-informed and community-led behavior change approaches are needed to ensure community participation and sustained behavioral changes in dengue prevention and control programs. The study demonstrated that locally identified solutions and community-made IEC materials had strong ownership and acceptance from the community. PD is an 'inside-out' community-led behavior change intervention that ensures active community participation throughout the process, which is a key requirement of vector control programs. Therefore, PD should be further replicated and scaled up to better determine the effectiveness of the approach. Positive deviance could be a potential behavior change tool to be adopted for dengue prevention and control in Pakistan and elsewhere.

Supplementary Materials: The following are available online at https: / www.mdpi.com/article/ 10.3390/insects13010071/s1, Figure S1: Community sensitization meeting with key community stakeholders. Figure S2: PD role models share their positive behaviors during the feedback session. Figure S3: PD health education session with female community members. Figure S4: An illustration made by a community member for the sketch competition.

Author Contributions: Conceptualization, M.S.; Methodology, M.S., M.M., C.A. and U.P.; Software, M.S.; Validation, M.S. and U.P.; Formal Analysis, M.S.; Investigation, M.S., M.M. and U.P., Resources, M.S.; Data Curation, M.S. and U.P.; Writing-Original Draft. Preparation: M.S.; Writing-Review \& Editing, M.S, M.M, C.A. and U.P.; Visualization, M.S.; Supervision, M.S. and U.P.; Project Administration, M.S. All authors have read and agreed to the published version of the manuscript.

Funding: This study received no external funding.

Institutional Review Board Statement: The study protocol was approved by the National Bioethics Committee, Pakistan in April 2020 (Ref: No.4-87/NBC-451/20/2037).

Informed Consent Statement: Informed consent was obtained from all subjects involved in the study. 
Data Availability Statement: The data sets are available and can be accessed on request from the author.

Acknowledgments: The author is highly indebted to Monique Sternin for her continuous support and guidance in the positive deviance concept and its operationalization. The author is very grateful to Laura Donovan for her detailed review and editing of the manuscript. The author is very obliged to the community members for their active participation in the study.

Conflicts of Interest: The author declares no conflict of interest.

\section{References}

1. Kraemer, M.U.G.; Sinka, M.E.; Duda, K.A.; Mylne, A.Q.N.; Shearer, F.M.; Barker, C.M.; Moore, C.G.; Carvalho, R.G.; Coelho, G.E.; Van Bortel, W.; et al. The global distribution of the arbovirus vectors Aedes aegypti and Ae. albopictus. eLife 2015, 4, e08347. [CrossRef]

2. Brady, O.J.; Gething, P.W.; Bhatt, S.; Messina, J.P.; Brownstein, J.S.; Hoen, A.G.; Moyes, C.L.; Farlow, A.W.; Scott, T.W.; Hay, S.I. Refining the Global Spatial Limits of Dengue Virus Transmission by Evidence-Based Consensus. PLoS Negl. Trop. Dis. 2012, 6, e1760. [CrossRef]

3. Mitra, A.K.; Mawson, A.R. Neglected Tropical Diseases: Epidemiology and Global Burden. Trop. Med. Infect. Dis. 2017, 2, 36. [CrossRef]

4. $\quad$ Bhatt, S.; Gething, P.W.; Brady, O.J.; Messina, J.P.; Farlow, A.W.; Moyes, C.L.; Drake, J.M.; Brownstein, J.S.; Hoen, A.G.; Sankoh, O.; et al. The global distribution and burden of dengue. Nature 2013, 496, 504-507. [CrossRef]

5. Guzman, M.G.; Gubler, D.J.; Izquierdo, A.; Martinez, E.; Halstead, S.B. Dengue infection. Nat. Rev. Dis. Primers 2016, $2,16055$. [CrossRef] [PubMed]

6. Messina, J.P.; Brady, O.J.; Scott, T.W.; Zou, C.; Pigott, D.M.; Duda, K.A.; Bhatt, S.; Katzelnick, L.; Howes, R.E.; Battle, K.E.; et al. Global spread of dengue virus types: Mapping the 70 year history. Trends Microbiol. 2014, 22, 138-146. [CrossRef]

7. Ebi, K.L.; Nealon, J. Dengue in a changing climate. Environ. Res. 2016, 151, 115-123. [CrossRef]

8. Murray, N.E.A.; Quam, M.B.; Wilder-Smith, A. Epidemiology of dengue: Past, present and future prospects. Clin. Epidemiol. 2013, 5, 299-309.

9. Khan, J.; Khan, I.; Ghaffar, A.; Khalid, B. Epidemiological trends and risk factors associated with dengue disease in Pakistan (1980-2014): A systematic literature search and analysis. BMC Public Health 2018, 18, 745. [CrossRef]

10. Rasheed, S.B.; Butlin, R.K.; Boots, M. A review of dengue as an emerging disease in Pakistan. Public Health 2013, 127, 11-17. [CrossRef]

11. Chan, Y.C.; Salahuddin, N.; Khan, J.; Tan, H.C.; Seah, C.L.K.; Li, J.; Chow, V.T.K. Dengue haemorrhagic fever outbreak in Karachi, Pakistan, 1994. Trans. R. Soc. Trop. Med. Hyg. 1995, 89, 619-620. [CrossRef]

12. Zahir, A.; Ullah, A.; Shah, M.; Mussawar, A. Community Participation, Dengue Fever Prevention and Control Practices in Swat, Pakistan. Int. J. MCH AIDS 2016, 5, 39-45. [CrossRef]

13. Abdullah, S.A.; Salman, M.; Din, M.; Khan, K.; Ahmad, M.; Khan, F.H.; Arif, M. Dengue Outbreaks in Khyber Pakhtunkhwa (KPK), Pakistan in 2017: An Integrated Disease Surveillance and Response System (IDSRS)-Based Report. Pol. J. Microbiol. 2019, 68, 115-119. [CrossRef]

14. Baloch, M.; Baig, A.M.; Ochani, R.K. Is Dengue the new rising global health problem? The outbreak of 2019 in Pakistan. Minerva Med. 2020. [CrossRef]

15. Capeding, M.R.; Tran, N.H.; Hadinegoro, S.R.; Ismail, H.I.; Chotpitayasunondh, T.; Chua, M.N.; Luong, C.Q.; Rusmil, K.; Wirawan, D.N.; Nallusamy, R.; et al. Clinical efficacy and safety of a novel tetravalent dengue vaccine in healthy children in Asia: A phase 3, randomised, observer-masked, placebo-controlled trial. Lancet 2014, 384, 1358-1365. [CrossRef]

16. Vannice, K.S.; Roehrig, J.T.; Hombach, J. Next generation dengue vaccines: A review of the preclinical development pipeline. Vaccine 2015, 33, 7091-7099. [CrossRef] [PubMed]

17. Echaubard, P.; Thy, C.; Sokha, S.; Srun, S.; Nieto-Sanchez, C.; Grietens, K.P.; Juban, N.R.; Mier-Alpano, J.; Deacosta, S.; Sami, M.; et al. Fostering social innovation and building adaptive capacity for dengue control in Cambodia: A case study. Infect. Dis. Poverty 2020, 9, 126. [CrossRef]

18. Al-Muhandis, N.; Hunter, P.R. The Value of Educational Messages Embedded in a Community-Based Approach to Combat Dengue Fever: A Systematic Review and Meta Regression Analysis. PLoS Negl. Trop. Dis. 2011, 5, e1278. [CrossRef] [PubMed]

19. Nguyen-Tien, T.; Probandari, A.; Ahmad, R.A.; Thang, N.T. Barriers to Engaging Communities in a Dengue Vector Control Program: An Implementation Research in an Urban Area in Hanoi City, Vietnam. Am. J. Trop. Med. Hyg. 2019, 100, 964-973. [CrossRef] [PubMed]

20. Zakus, J.D.; Lysack, C.L. Revisiting community participation. Health Policy Plan 1998, 13, 1-12. [CrossRef] [PubMed]

21. Wai, K.T.; Htun, P.T.; Oo, T.; Myint, H.; Lin, Z.; Kroeger, A.; Sommerfeld, J.; Petzold, M. Community-centred eco-bio-social approach to control dengue vectors: An intervention study from Myanmar. Pathog. Glob. Health 2012, 106, 461-468. [CrossRef] [PubMed] 
22. Toledo, M.; Vanlerberghe, V.; Baly, A.; Ceballos, E.; Valdes, L.; Searret, M.; Boelaert, M.; Van Der Stuyft, P. Towards active community participation in dengue vector control: Results from action research in Santiago de Cuba, Cuba. Trans. R. Soc. Trop. Med. Hyg. 2007, 101, 56-63. [CrossRef] [PubMed]

23. Vanlerberghe, V.; Toledo, M.E.; Rodríguez, M.; Gomez, D.; Baly, A.; Benitez, J.R.; Van der Stuyft, P. Community involvement in dengue vector control: Cluster randomised trial. BMJ 2009, 338, b1959. [CrossRef] [PubMed]

24. Shafique, M.; Lopes, S.; Doum, D.; Keo, V.; Sokha, L.; Sam, B.; Vibol, C.; Alexander, N.; Bradley, J.; Liverani, M.; et al. Implementation of guppy fish (Poecilia reticulata), and a novel larvicide (Pyriproxyfen) product (Sumilarv 2MR) for dengue control in Cambodia: A qualitative study of acceptability, sustainability and community engagement. PLoS Negl. Trop. Dis. 2019, 13, e0007907. [CrossRef] [PubMed]

25. Ahrari, M.; Houser, R.F.; Yassin, S.; Mogheez, M.; Hussaini, Y.; Crump, P.; Darmstadt, G.L.; Marsh, D.; Levinson, F.J. A Positive Deviance-based Antenatal Nutrition Project Improves Birth-weight in Upper Egypt. J. Health Popul. Nutr. 2006, 24, 498-507. [PubMed]

26. Fowles, E.R.; Hendricks, J.A.; Walker, L.O. Identifying Healthy Eating Strategies in Low-Income Pregnant Women: Applying a Positive Deviance Model. Health Care Women Int. 2005, 26, 807-820. [CrossRef]

27. Kanani, S.; Popat, K. Growing Normally in an Urban Environment: Positive Deviance among Slum Children of Vadodara, India Indian J. Pediatr. 2012, 79, 606-611. [CrossRef]

28. Ndiaye, M.; Siekmans, K.; Haddad, S.; Receveur, O. Impact of a Positive Deviance Approach to Improve the Effectiveness of an Iron-Supplementation Program to Control Nutritional Anemia among Rural Senegalese Pregnant Women. Food Nutr. Bull. 2009, 30, 128-136. [CrossRef] [PubMed]

29. Gabbay, R.A.; Friedberg, M.W.; Miller-Day, M.; Cronholm, P.F.; Adelman, A.; Schneider, E.C. A Positive Deviance Approach to Understanding Key Features to Improving Diabetes Care in the Medical Home. Ann. Fam. Med. 2013, 11, S99-S107. [CrossRef]

30. Shafique, M.; Edwards, H.M.; De Beyl, C.Z.; Thavrin, B.K.; Min, M.; Roca-Feltrer, A. Positive deviance as a novel tool in malaria control and elimination: Methodology, qualitative assessment and future potential. Malar. J. 2016, 15, 91. [CrossRef] [PubMed]

31. Marsh, D.R.; Sternin, M.; Khadduri, R.; Ihsan, T.; Nazir, R.; Bari, A.; Lapping, K. Identification of Model Newborn Care Practices through a Positive Deviance Inquiry to Guide Behavior-Change Interventions in Haripur, Pakistan. Food Nutr.Bull. 2002, 23, 107-116. [CrossRef]

32. Lapping, K.; Marsh, D.R.; Rosenbaum, J.; Swedberg, E.; Sternin, J.; Sternin, M.; Schroeder, D.G. The positive deviance approach Challenges and opportunities for the future. Food Nutr. Bull. 2002, 23, 130-137. [CrossRef]

33. Marsh, D.R.; Schroeder, D.G.; A Dearden, K.; Sternin, J.; Sternin, M. The power of positive deviance. BMJ 2004, 329, 1177-1179. [CrossRef]

34. Mackintosh, U.A.T.; Marsh, D.R.; Schroeder, D.G. Sustained positive deviant child care practices and their effects on child growth in Viet Nam. Food Nutr. Bull. 2002, 23, 18-27. [CrossRef]

35. Faul, F.; Erdfelder, E.; Buchner, A.; Lang, A.-G. Statistical power analyses using G*Power 3.1: Tests for correlation and regression analyses. Behav. Res. Methods 2009, 41, 1149-1160. [CrossRef] [PubMed]

36. Hanklang, S.; Ratanasiripong, P.; Sivasan, S. Effectiveness of the intervention program for dengue hemorrhagic fever prevention among rural communities in Thailand. J. Health Res. 2018, 32, 352-363. [CrossRef]

37. Kumaran, E.; Doum, D.; Keo, V.; Sokha, L.; Sam, B.; Chan, V.; Alexander, N.; Bradley, J.; Liverani, M.; Prasetyo, D.B.; et al. Dengue knowledge, attitudes and practices and their impact on community-based vector control in rural Cambodia. PLoS Negl. Trop. Dis. 2018, 12, e0006268. [CrossRef]

38. Hustedt, J.C.; Doum, D.; Keo, V.; Ly, S.; Sam, B.; Chan, V.; Alexander, N.; Bradley, J.; Liverani, M.; Prasetyo, D.B.; et al. Field Efficacy of Larvivorous Fish and Pyriproxyfen Combined with Community Engagement on Dengue Vectors in Cambodia: A Randomized Controlled Trial. Am. J. Trop. Med. Hyg. 2021, 105, 1265-1276. [CrossRef]

39. Parks, W.; Lloyd, L. Planning Social Mobilization and Communication for Dengue Fever Prevention and Control: A Step-by-Step Guide; World Health Organization: Geneva, Switzerland, 2004.

40. Gubler, D.J.; Clark, G.G. Community-Based Integrated Control of Aedes Aegypti: A Brief Overview of Current Programs. Am. J. Trop. Med. Hyg. 1994, 50, 50-60. [CrossRef]

41. Hone, T.; Macinko, J.; Millett, C. Revisiting Alma-Ata: What is the role of primary health care in achieving the Sustainable Development Goals? Lancet 2018, 392, 1461-1472. [CrossRef]

42. Rifkin, S.B. Paradigms lost: Toward a new understanding of community participation in health programmes. Acta Trop. 1996, 61, 79-92. [CrossRef]

43. Figueroa, M.E.; Kincaid, D.L.; Rani, M.; Lewis, G. Communication for Social Change: An Integrated Model for Measuring the Process and Its Outcomes; The Rockefeller Foundation: New York, NY, USA, 2002.

44. Castro, M.; Sánchez, L.; Pérez, D.; Carbonell, N.; Lefèvre, P.; Vanlerberghe, V.; Van der Stuyft, P. A community empowerment strategy embedded in a routine dengue vector control programme: A cluster randomised controlled trial. Trans. R. Soc. Trop. Med. Hyg. 2012, 106, 315-321. [CrossRef]

45. Caprara, A.; Lima, J.W.D.O.; Peixoto, A.C.R.; Motta, C.M.V.; Nobre, J.M.S.; Sommerfeld, J.; Kroeger, A. Entomological impact and social participation in dengue control: A cluster randomized trial in Fortaleza, Brazil. Trans. R. Soc. Trop. Med. Hyg. 2015, 109, 99-105. [CrossRef] 
46. Tyagi, B.K.; Samuel, M.; Krishnamoorthi, R.; Manavalan, R.; Tewari, S.C.; Ashokkumar, V.; Kroeger, A.; Sommerfeld, J.; Petzold, M. Community-based control of Aedes aegypti by adoption of eco-health methods in Chennai City, India. Pathog. Glob. Health 2012, 106, 488-496.

47. Lloyd, L.S.; Winch, P.; Ortega-Canto, J.; Kendall, C. The Design of a Community-Based Health Education Intervention for the Control of Aedes aegypti. Am. J. Trop. Med. Hyg. 1994, 50, 401-411. [CrossRef] [PubMed]

48. Atkinson, J.-A.; Vallely, A.; Fitzgerald, L.; Whittaker, M.; Tanner, M. The architecture and effect of participation: A systematic review of community participation for communicable disease control and elimination. Implications for malaria elimination. Implications for malaria elimination. Malar. J. 2011, 10, 225. [CrossRef] 